\title{
Clinical and histopathological features of horn core carcinoma in a Nellore cow - case report
}

\section{Aspectos clínicos e histopatológicos do carcinoma da base do chifre em uma vaca Nelore - relato de caso}

\author{
Roberta Garbelini Gomes ${ }^{1}$; Leandro Américo Rafael ${ }^{2}$; \\ Selwyn Arlington Headley ${ }^{3}$; Augusto Jose Savioli de Almeida Sampaio ${ }^{4 *}$
}

\begin{abstract}
This manuscript describes the clinical and pathological findings associated with a unilateral horn core carcinoma in a 12- year-old, Nellore cow. Initially the cow presented a small growth within the right horn with consequent hanging of the affected horn and progressive increase in size of the mass, ultimately resulting in a large space occupying tumorous growth. Clinical laboratory evaluations revealed non-regenerative anemia; while bacteriological analyses yielded cultures of Pseudomonnas spp. and Arcanobacterium spp. Histopathology revealed the mass to be consisted predominantly of a well differentiated squamous cell carcinoma with areas of neoplastic glandular epithelium. The anatomic location of the tumor associated with the histopathological findings is consistent with horn core carcinoma of cattle.
\end{abstract}

Key words: Bovine, neoplasm, cutaneous diseases, histopathology

\section{Resumo}

Este manuscrito descreve os achados clínicos e patológicos associados com um carcinoma da base do chifre de uma vaca da raça Nelore de 12 anos de idade. Inicialmente a vaca apresentou uma pequena massa dentro do seio do corno direito com aumento progressivo no tamanho, que se evidenciou após a fratura do mesmo, que permaneceu pendurado por um pequeno fragmento de pele. Essa lesão resultou em uma enorme massa exuberante. Os exames laboratoriais revelaram anemia arregerenativa; as análises bacteriológicas produziram culturas de Pseudomonnas spp. E Arcanobacterium spp. A avaliação histopatológica revelou que a massa era formada predominantemente pelo carcinoma das células escamosas bem-diferenciado com áreas de neoplasia do epitélio glandular. A localização anatômica do tumor associado aos achados histopatológicos é consistente com o carcinoma da base do chifre.

Palavras-chave: Bovino, neoplasia, doença cutânea, histopatologia

\footnotetext{
${ }^{1}$ Prof ${ }^{a}$ Assistente, Doutoranda em Ciência Animal , Dept ${ }^{\circ}$ de Clínicas Veterinárias, Universidade Estadual de Londrina, Londrina, PR. E-mail: garbelinirg@uel.br

${ }^{2}$ Residente da Clínica Médica, Cirúrgica e Reprodução de Grandes Animais, UEL, Londrina, PR. E-mail: leamerico@hotmail.com

${ }^{3}$ Prof. Pesquisador da Universidade Norte do Paraná, UNOPAR, Londrina, PR. E-mail: headleysa@gmail.com

${ }^{4}$ Prof. Associado do Dept ${ }^{\circ}$ de Clínicas Veterinárias, UEL, Londrina, PR. E-mail: asampaio@uel.br

* Author for corespondence
} 


\section{Introduction}

Horn core carcinoma, also known as horn cancer, is a malignant neoplastic growth derived from proliferating squamous epithelial cells (GINN; MENSETT; RUKICH, 2007). Although the origin of this tumor is not well elucidated, the neoplasm probably arises from the mucous membranes of the sinuses and then invades the horn (PULLEY; STANNARD, 1990). Horn cancer is of significant importance in India where approximately $1 \%$ of the bovine population might be affected (NAIK; RANDELIA; DABHOLKAR, 1970), resulting in severe economic loss (SOMVANSHI, 1991). Animals chronically affected might demonstrate progressive emaciation, anemia, eventually resulting in death (PULLEY; STANNARD, 1990; LEMOS; NAKAZATO, 2001).

Although horn core carcinoma occurs almost exclusively in castrated male cattle in India (SOMVANSHI, 1991; GINN; MENSETT; RUKICH, 2007) with cases occurring in Iraq (ZUBAIDY, 1976), there are few descriptions of this lesion in cattle from Brazil (LEMOS; NAKAZATO, 2001). Cases of this tumor in Brazil were described in the states of Minas Gerais (NASCIMENTO et al., 1975), Mato Grosso, São Paulo (LEMOS; NAKAZATO, 2001), and Paraná (KELLER et al., 2008). Grossly the tumor is found within the core of the horn and invariably destroys the horn, resulting in invasion of adjacent sinuses and cranial bone (GINN; MENSETT; RUKICH, 2007); involvement of the meninges has also been described (KELLER et al., 2008). By histopathology, horn core neoplasia is a well-differentiated squamous cell carcinoma (PULLEY; STANNARD, 1990; GINN; MENSETT; RUKICH, 2007). This report describes the clinical and pathological findings associated with horn core carcinoma in a Nellore cow, and adds to the characterization of this unusual neoplasm in Brazil.

\section{Case Report}

A 12-year-old, female Nellore cow, which originated from Cambé, Paraná was referred to the
Veterinary Teaching Hospital (VTH), Universidade Estadual de Londrina, Paraná in early June, 2008. The cow had a complaint of a broken right horn that occurred approximately two months earlier; initially a small growth was observed within the horn core by the consulting veterinarian who noticed that the affected horn remained hanging. However, on removal of the affected horn, constant increase in the size of the mass was observed by the consulting veterinarian, who related that the mass resulted in a large non-cicatrizing, foul-smelling, lesion that partially occupied the adjoining sinuses; the lesion was considered as a large granulation tissue. The consulting veterinarian also related that attempts to successfully drain and treat the lesion were frustrated, resulting in progressive increase in the size of the affected region.

Clinical evaluation at the VTH-UEL revealed a large $(13 \times 16.5 \mathrm{~cm})$, space-occupying exuberant mass within the base of the right cornual process (Figure 1A); all vital signs were within physiological limits. Grossly, the mass was highly vascular, reddish-brown in color, of spongy-like consistency, with ulcerated borders, several nodular areas, and contained a foul-smelling serous secretion. The growth was surgically removed and submitted for routine histopathological evaluation; the putrid secretion was aseptically collected for bacterial analyses; and a routine hematological profile was solicited.

Histopathology revealed a tumor formed by the proliferation of squamous epithelial cells that invaded the underlying dermis and resulted in superficial ulceration (Figure 1B). The neoplastic epithelial cells were arranged in solid expansive sheets or islands of squamous neoplastic cells; some of these islands/sheets contained keratin pearls (Figure 1C). The neoplastic cells demonstrated severe nuclear and cellular pleomorphism, elevated mitotic index (4-5 per 40x Obj.) with numerous atypical mitotic figures; some cells contained two or three nucleoli (Figure 1D-E). Additionally, there was severe necrosis, hemorrhage, and neutrophilic exudate between and surrounding the neoplastic 
growth. In other tissue fragments submitted, a neoplastic growth formed by proliferating epithelial cells that produced a distinct glandular pattern was observed; these neoplastic glandular-like formations were surrounded by fibrous connective tissue of varying thickness (Figure 1F-G). In some tissue sections, the squamous and glandular-like proliferative growths were adjacent (Figure 1H).

Figure 1. Gross and histopathological features of horn core carcinoma in a Nellore cow. There is large ulcerative neoplastic mass at the base of the right horn (A). Observe proliferation of squamous epithelial cells into the underling dermis and areas of superficial ulceration (B). There is proliferation of an expansive sheet of neoplastic epithelial cells with the formation of keratin pearls (arrows) within the neoplastic growth (C). There is nuclear and cellular pleomorphism and several cells containing bi- and tri-nucleoli (arrows) (D), and atypical (arrow) mitotic figures (E). Observe proliferation of glandular-like epithelium (F), which is embedded in connective tissue $(\mathrm{G})$, and the adjacent location of the glandular and squamous neoplastic cells (H). B-H; Hematoxylin and eosin stain; B, 4 x Obj,; C, F, and H, 10 x Obj.; D-E, G, 40x Obj.

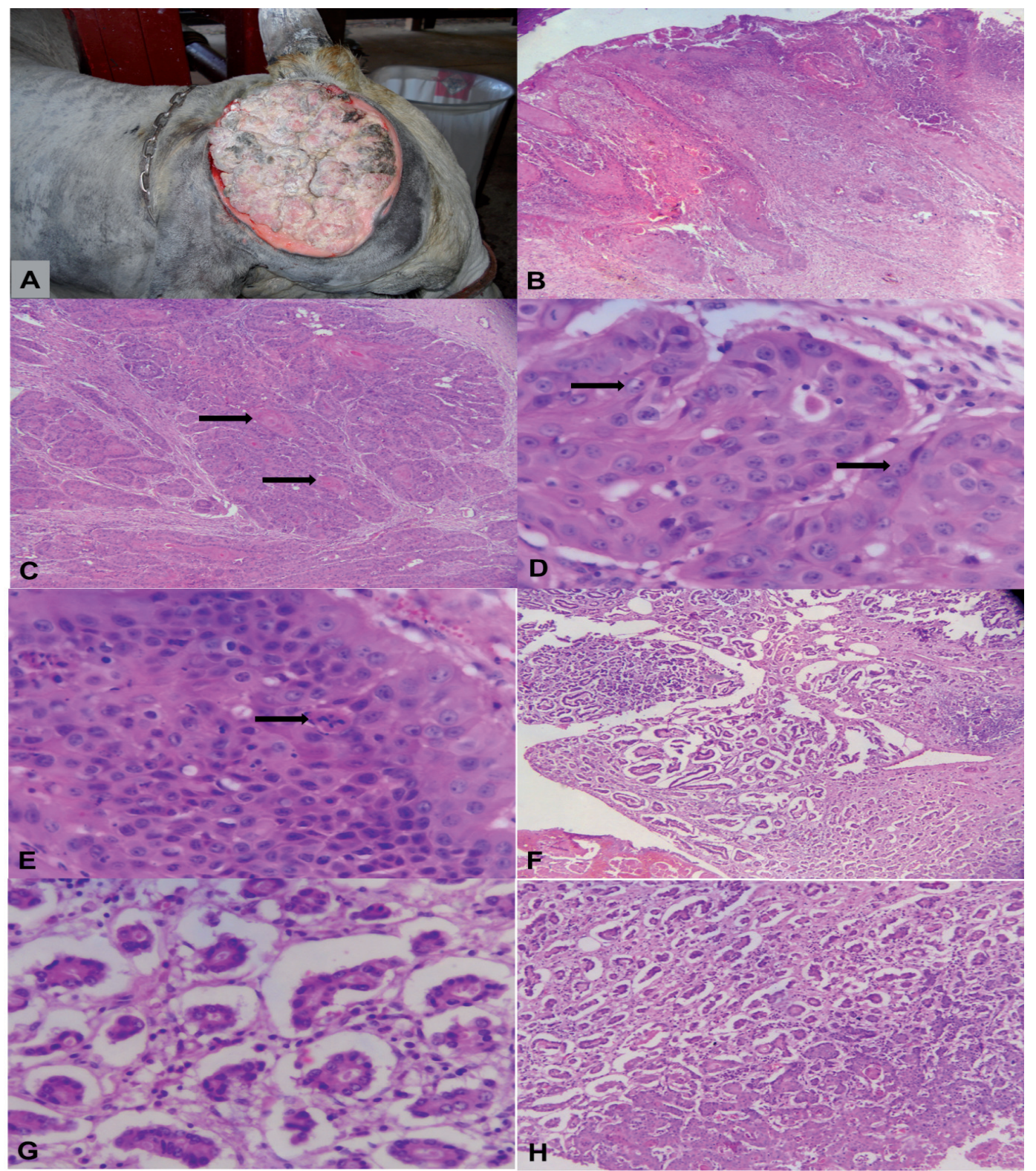

Source: Elaboration of the authors. 
Bacteriological analyses revealed cultures of Pseudomonnas spp. and Arcanobacteriumspp. The hematologic investigation demonstrated a severe reduction in the values of hematocrit ( $18 \%$; reference value, $24-46 \%)$, hemoglobin $(6.0 \mathrm{~g} / \mathrm{dl}$; reference range, $8-15 \mathrm{~g} / \mathrm{dl}$ ), and red blood cells (4.62cells/ $\mathrm{mm}^{3}$; reference range, $5-10$ cells $\left./ \mathrm{mm}^{3}\right)$. The total leukocytes count was $6900 \mathrm{~mm}^{3}$ (reference range, 4-12 $\left.\mathrm{mm}^{3}\right)$; with neutrophilia ( $63 \%$; reference range, $15-45 \%$ ) and lymphopenia (34\%; reference range, 45-75), but without alteration to eosinophils ( $2 \%$; reference range, 2-20\%). Additionally, fibrinogen values (800 mg/dl; reference range, 300-700) were elevated with the amount of total proteins being within physiological limits $(7.8 \mathrm{mg} / \mathrm{dl}$; reference range, $7-8.5 \mathrm{mg} / \mathrm{dl})$.

A diagnosis of horn core carcinoma was established based on the anatomic location of the mass and the histopathological features which are consistent with this neoplasm (PULLEY; STANNARD, 1990; GINN; MENSETT; RUKICH, 2007). This tumor was histologically classified as a well-differentiated squamous cell carcinoma of the right horn; similar results were described in cases within Brazil (NASCIMENTO et al., 1975; REZENDE; NEVES, 1975; KELLER et al., 2008).

This case represents a rare description of this neoplasm in a Nellore cow from Brazil, since the tumor is predominant in cattle of Indian origin (PULLEY; STANNARD, 1990) or imported from India (LEMOS; NAKAZATO, 2001), as occurred in a few cases of this neoplasm described in Brazil (REZENDE; NEVES, 1975). Although the reason for an elevated occurrence of horn core carcinoma in cows from India relative to other countries is not well established, the method of cattle rearing and the final economic outcome might be the key. In India cattle is raised predominantly for cultural and religious purposes with milk production for household subsistence being the most significant economic activity. Further, India seems to be the only country where for ethnic reasons cows are maintained alive until spontaneous death in their terminal life cycle (NAIK; RANDELIA; DABHOLKAR, 1970; SOMVANSHI, 1991). Therefore, this pattern of cattle production promotes the maintenance of animals for a considerable longer period of time (NAIK; RANDELIA; DABHOLKAR, 1970); where older animals are more susceptible to develop neoplasms, not only of the horn core, but neoplastic growths as a whole. However, the scenario is completely different in western countries, like Brazil, where cattle production is predominantly an economic activity resulting in animals being slaughtered at a considerably earlier age; thereby significantly reducing the risk of developing neoplastic growths. This might explain the relatively low incidence of this neoplasm in Nellore cattle raised in Brazil for commercial production. Nevertheless, it is important to mention that this cow was used exclusively for embryo transfer; suggesting that due to the elevated economic value and zootechnical potentials of this cow she was maintained alive beyond the age at which animals in Brazil are normally slaughtered. This extended life based on specific economic explorations of cattle in western societies might then contribute to the finding of more neoplastic growths in cattle.

Epidemiological studies have suggested that horn cancer occurs predominantly in cattle that are more than eight years of age (SOMVANSHI, 1991; LEMOS; NAKAZATO, 2001), with no cases being described in animals that are below 4-years-of-age (SOMVANSHI, 1991); this cow was 12 years-old. Further, the few reports of horn core carcinoma in Nellore cattle raised in Brazil were diagnosed in cows that were beyond their normal economic productive cycle, and classified as old (REZENDE; NEVES, 1975) or 11 years-of-age (KELLER et al., 2008), as was this case; these findings further suggest that the occurrence of this neoplastic growth in cattle might be age-related and correlate with the economic activity to which the animal is exposed.

Although the actual etiology of horn core carcinoma remains unresolved, several factors 
have been proposed as predisposing animals to this neoplasm: genetic susceptibility, solar radiation, hormone imbalances, virus induction, or a combination of these (SOMVANSHI, 1991). The economic activities in which cattle are actively involved, as occurred in this case, might also predispose cows to neoplastic transformation due to extended natural life. However, trauma seems not to have any significant effect on the development of horn carcinoma (GINN; MENSETT; RUKICH, 2007), as was previously suggested (SOMVANSHI, 1991). The clinical history from this case seems to support this theory; since the consulting veterinarian indicated that the right horn was hanging which on inspection revealed that there was a small unusual growth within the horn core with similar tissues in the frontal sinuses; these were interpreted as granulation tissue. It was also related by the consulting veterinarian that after initial therapy there was unusual expansion of the mass resulting in compressive dilation of the horn core, due to the expanding mass. This might then indicate that the neoplastic growth probably impaired the structure of the horn which then became susceptible to fracture. Consequently, trauma might not be associated with the development of horn carcinoma (GINN; MENSETT; RUKICH, 2007), but rather a manifestation of the weakened bone tissue of the horn. Similar findings were reported in Iraq (ZUBAIDY, 1976), where cases of horn carcinomas were observed after the broken horn was removed surgically with extension of the neoplastic growth into the frontal sinuses in one described case.

Of significant interest in this case was the finding of neoplastic glandular component within some tissue sections. This glandular tissue might have originated from the paranasal sinuses, which are in close proximity with the junction of the horn (SAMUELSON, 2007), and could have been the origin of the neoplastic growth, considering that the proliferated mucosa of the paranasal sinuses is thought to be the initial manifestation of neoplastic development with subsequent invasion of the horn (PULLEY; STANNARD, 1990). Similar findings were described in cases of horn carcinoma in cows originated from India where columnar epithelia cells from mucous membrane of the horn base were considered as being transformed into squamous cell carcinoma (SOMVANSHI, 1991).

Unique to this case was the isolation of Arcanobacterium spp. from the fetid secretion contained within the tumor; this was not previously described in cases of horn core carcinoma. Although a similar secretion was reported in a cow from Minas Gerais (NASCIMENTO et al., 1975) and Iraq (ZUBAIDY, 1976), bacterial characterization was not done. Arcanobacterium pyogenes is frequently associated with purulent cutaneous lesions and abscesses in cattle (GINN; MENSETT; RUKICH, 2007), while Pseudomonnas spp. is a well-known contaminant. Invasion of secondary infectious agents in cases of horn cancer is not restricted to bacterial organisms; since Aspergillus terreuswas isolated in a case from India (PAL, 1989), and screwworm infestations are frequently observed within these neoplastic growths (LEMOS; NAKAZATO, 2001).

The hematological analyses are consistent with chronic non-regenerative anemia; anemia is a frequent manifestation of this neoplastic growth (SOMVANSHI, 1991; LEMOS; NAKAZATO, 2001). The neutrophilia observed in this case would more likely represent a manifestation of the severe bacterial infection observed within the neoplastic growth. However, eosinophilia, described as a frequent manifestation in advance cases of horn cancer (SOMVANSHI, 1991), was not observed in this case. This animal died three months after being discharged from the VTH-UEL, with apparent impairment of brain functions, since a telephone interview with the consulting veterinarian revealed that there were neurological manifestations before the animal died spontaneously; but a necropsy was not performed. Involvement of nervous tissue has been described in cases of horn core carcinoma (KELLER et al., 2008), probably due to invasion of the cranial bone and frontal sinuses (PULLEY; STANNARD, 1990). 
In conclusion, a unilateral horn core carcinoma was diagnosed by histopathology in a 12-year-old Nellore cow. The neoplastic growth contained a fetid secretion that revealed cultures of Pseudomonnas spp. and Arcanobacterium spp. which were considered as secondary bacterial contaminants. The few descriptions of horn core carcinoma in animals raised in Brazil might be directly related to the economic activity of cattle rearing and production, during which most animas are slaughtered at an early age, thereby reducing the risk of developing neoplastic growths.

\section{Acknowledgements}

The authors are extremely indebted to Dr. Yuna Ortenzi Bastos for the submission of this cow for clinical evaluation at the Veterinary Teaching Hospital, Universidade Estadual de Londrina.

\section{References}

GINN, P. E.; MENSETT, J. E. K. L.; RUKICH, P. M. Skin and appendages. In: MAXIE, M. Jubb, kennedy \& palmer's pathology of domestic animals. 5. ed. Philadelphia: Saunders/Elsevier, 2007. v. 1, p. 553-781.

KELlER, D.; RÖNNAU, M.; GUSMÃO, M. A.; TORRES, M. B. A. M. Casuística de carcinoma epidermóide cutâneo em bovinos do Campus Palotina da UFPR. Acta Scientiae Veterinariae, v. 36, n. 2, p. 155$159,2008$.
LEMOS, R. A. A.; NAKAZATO, L. Carcinoma de base de chifre. In: RIET-CORREA, F.; SCHILD, A. L.; MÉNDEZ, M. D. C.; LEMOS, R. A. A. (Ed.). Doenças de ruminantes e equinos. 2. ed. Santa Maria: Pallotti, 2001. v. 2, p. 544-546.

NAIK, S. N.; RANDELIA, H. P.; DABHOLKAR, R. D. Carcinoma of the horn in a cryptorchidbull. Pathologic Veterinary, v. 7, p. 265-469, 1970.

NASCIMENTO, E. F.; SILVA, J. M. L.; LÚCIO, W. F.; MELLO, M. A. Carcinoma espino-celular de base de chifre em bovino. Arquivo da Escola de Veterinária da $U F M G$, Minas Gerais, v. 27, n. 1, p. 39-43, 1975.

PAL, M. Colonization of squamous cell carcinoma in the bovine horn core by Aspergillus terreus. Mycoses, v. 32, p. 197-199, 1989.

PULLEY, L. T.; STANNARD, A. A. Tumors of the skin and soft tissues. In: MOULTON, J. E. (Ed.). Tumors in domestic animals. 3. ed. Davis: California University Press, 1990. p. 16-74.

REZENDE, A. M. L.; NEVES, P. T. Carcinoma do chifre em zebuíno importado. Pesquisa Agropecuária Brasileira, Série Veterinária, Brasília, v. 10, n. 8, p. 4144, 1975.

SAMUELSON, D. A. Text book of veterinary histology. St. Lious, Missouri, 2007. 546 p.

SOMVANSHI, R. Horn cancer in Indian cattle. Veterinary Bulletin, v. 61, n. 9, p. 901-11, 1991.

ZUBAIDY, A. J. Horn cancer in cattle in Iraq. Veterinary Pathology, USA, v. 13, 453-454, 1976. 